\title{
Genetic diversity and structure of two species of Enyalius (Squamata: Leiosauridae) from neotropical biodiversity hotspots
}

\author{
Sarah M. Vargas ${ }^{1,2}$, Marcelo de Oliveira Santos ${ }^{3}$, Iara Alves Novelli ${ }^{2}$, Celso Henrique Varela- \\ Rios $^{2}$, Lúcio Moreira Campos Lima², Priscila da Silva Lucas², Pilar Cozendey ${ }^{4}$, Raquel Morais \\ Paiva $^{3}$, Samuel Campos Gomides ${ }^{5}$, Sara Malaguti ${ }^{3}$, and Bernadete Maria de Sousa ${ }^{2,4}$ \\ ${ }^{1}$ Departamento de Ciências Biológicas, Centro de Ciências Humanas e Naturais, Universidade Federal do Espírito Santo, \\ 29.043-900, Vitória, Espírito Santo, Brazil. E-mail: sarahmvbio@gmail.com. \\ ${ }^{2}$ Programa de Pós-Graduação em Ciências Biológicas, Comportamento e Biologia Animal, Universidade Federal de Juiz de \\ Fora, 36.036-900, Juiz de Fora, Minas Gerais, Brazil. E-mail: bernadete.sousa@gmail.com. \\ ${ }^{3}$ Programa de Pós-Graduação em Ciências Biológicas, Imunologia e Genética, Universidade Federal de Juiz de Fora, $36.036-$ \\ 900, Juiz de Fora, Minas Gerais, Brazil. E-mail: marcelo.santosufjf@gmail.com. \\ ${ }^{4}$ Programa de Pós-Graduação em Ciências Biológicas, Ecologia, Universidade Federal de Juiz de Fora, 36.036-900, Juiz de \\ Fora, Minas Gerais, Brazil. E-mail: cozendey@ gmail.com. \\ ${ }^{5}$ Laboratório de Herpetologia, Departamento de Zoologia, Instituto de Ciências Biológicas, Universidade Federal de Minas \\ Gerais, Av. Antônio Carlos, 6627, CEP 31270-901, Belo Horizonte, Minas Gerais, Brazil. E-mail: samuelbio@ hotmail.com.
}

\begin{abstract}
Genetic diversity and structure of two species of Enyalius (Squamata: Leiosauridae) from neotropical biodiversity hotspots. Enyalius, a lizard genus endemic to South America, is mostly distributed in the remains of the Atlantic Forest and in the Cerrado. The genus has been the topic of a few studies but none has quantified the genetic diversity and structure within and among populations of Enyalius. The genetic diversity and structure of populations of E. bilineatus $(N=20)$ and E. perditus $(N=28)$ are examined using a 234-bp fragment of the cytochrome $\mathrm{b}$ gene and compared with the sequences reported in other published data. Nineteen distinct haplotypes (eleven for E. perditus and eight for $E$. bilineatus) were found, eight of which were recorded for the first time. The haplotype diversities are highly similar for both species ( 0.684 for E. perditus and 0.647 for $E$. bilineatus). The genetic distance between the two species is $20.3 \%$ and the distance within species is $2.0 \%$ and $5.6 \%$ for E. perditus and E. bilineatus, respectively. Our data suggest that populations of E. bilineatus are genetically divergent and may reveal cryptic diversity. This is the first study to quantify the genetic diversity of species of Enyalius from Neotropical biodiversity hotspots. These data facilitate a better understanding of both
\end{abstract}

Received 28 May 2015.

Accepted 28 September 2015.

Distributed December 2015. 
within and among population variation, and highlight the distribution of genetic lineages of an endemic and poorly studied genus.

Keywords: Atlantic Forest, Cerrado, cytochrome b (cyt b), Enyalius bilineatus, Enyalius perditus.

\begin{abstract}
Resumo
Diversidade e estrutura genética de duas espécies de Enyalius (Squamata: Leiosauridae) em hotspots neotropicais de biodiversidade. Os lagartos do gênero Enyalius são endêmicos da América do Sul, sendo predominantemente encontrados no Cerrado e em fragmentos da Floresta Atlântica. Este é um gênero pouco estudado, e não foram encontrados dados relacionados à diversidade e à estrutura genética das espécies do gênero. Neste trabalho, investigamos a diversidade genética de populações de E. bilineatus $(N=20)$ e E. perditus $(N=28)$, usando um fragmento de 234-pb do citocromo b, e comparamos as sequências geradas com outras publicadas. Dezenove haplótipos distintos foram encontrados (11 de E. perditus e oito de E. bilineatus), sendo oito deles novos registros. Os valores de diversidade haplotípica foram muito similares para as duas espécies $(0.684$ para E. perditus e 0.647 para E. bilineatus). A distância genética entre as duas espécies foi de $20.3 \%$, e as distâncias intraespecíficas foram $2.0 \%$ para E. perditus e $5.6 \%$ para E. bilineatus. Nossos dados sugerem que as populações de E. bilineatus são altamente divergentes e que a espécie deve apresentar diversidade críptica. Este é o primeiro estudo medindo a diversidade genética de espécies do gênero Enyalius oriundas de regiões consideradas hotspots da biodiversidade neotropical e apresenta dados relevantes para um melhor entendimento das relações inter e intrapopulacionais, assim como a distribuição das linhagens genéticas desse gênero endêmico.
\end{abstract}

Palavras-chave: Cerrado, citocromo b (cit b), Enyalius bilineatus, Enyalius perditus, Floresta Atlântica.

\section{Introduction}

Ecological, demographic, and genetic studies provide critical data for conservation studies. Data documenting the genetic structure and levels of genetic diversity within and between populations are useful in the formulation of conservation strategies that ensure a species or local populations retain sufficient genetic diversity to respond to environmental change (O’Brien 1994, Wallace et al. 2011). Thus, maintenance of genetic diversity is an important factor in fostering adaptative evolution in the medium and long terms in natural populations (Santos and Redondo 2003, Frankham et al. 2010).

Enyalius (Leiosauridae) comprises at least 10 endemic South American taxa; systematic relationships among these taxa are challenging given the variation in their color patterns (Rodrigues et al. 2014). The species are widely distributed through the Atlantic Forest; one species is found in the Amazon, and others occur in remote locations of the Caatinga and Cerrado gallery forests (Etheridge 1969, Vanzolini 1973, Jackson 1978, Ávila-Pires 1995). Enyalius perditus occurs in remnants of the Atlantic Forest in the states of Rio de Janeiro, São Paulo, Paraná, and Minas Gerais (Jackson 1978, Sousa et al. 2012). Enyalius bilineatus inhabits regions of the Atlantic Forest in the states of Minas Gerais, Rio de Janeiro and Espírito Santo and areas of Cerrado and Caatinga habitats in Minas Gerais (Etheridge 1969, Jackson 1978, Zamprogno et al. 2001, Bertolotto et al. 2002, Colli 2003, Sousa et al. 2010, Novelli et al. 
2012). Enyalius bilineatus is sympatric with $E$. perditus at high elevations in the Atlantic Forest (Barreto-Lima 2012, Rodrigues et al. 2014).

The few studies that examine the distribution (Barreto-Lima 2012) and evolutionary history of these species (Bertolotto 2006, Rodrigues et al. 2014) emphasize the need to increase the number of localities sampled to better understand the relationship between the levels of genetic diversities, genetic structure, and phylogeny of the genus. These data will reveal cryptic diversity and inform effective conservation actions. Based on an analysis of chromosomes, and mitochondrial and nuclear markers from Enyalius spp., Bertolotto (2006) identified two divergent lineages of E. bilineatus from Minas Gerais; the author suggested that $E$. bilineatus represented two different species. In a more inclusive biogeographic study, Rodrigues et al. (2014) examined the 10 recognized species of Enyalius from 51 Brazilian localities; they reported high diversity and several taxonomic problems. The authors found E. perditus to be paraphyletic and E. bilineatus to contain cryptic diversity expressed as two coherent, divergent geographic clades. None of the locations sampled in this study was included in previous studies; therefore, the new data presented herein provide important records on genetic structure of these species, as well as useful information that can be applied to future taxonomic decisions.

Neither Enyalius perditus nor E. bilineatus is cited in the Brazilian list of threatened species (Martins and Molina 2008) or the Red List of the International Union for Conservation of Nature (IUCN 2015). We think there are insufficient data to assess the status of the species properly. Both species are relatively abundant in the areas that we targeted; thus, we were able to collect appropriate numbers of samples (desirable greater than five per location) to perform a sound population genetic study.

We propose to increase the knowledge about the genetic diversity of lizards from the Atlantic Forest and Cerrado regions. Specifically, we aimed to: (1) understand the distributions of the genetic variation of the two species of Enyalius in the fragments studied; (2) reveal evidence of cryptic diversity for $E$. bilineatus based on the cyt $b$ fragment, as well as from samples at two additional localities; (3) analyze the paraphyly of $E$. perditus on the basis of specimens from three additional locations; and (4) to analyze the relationship among the $E$. perditus and $E$. bilineatus cyt $b$ haplotypes from novel locations and compare our results with other published data.

\section{Materials and Methods}

\section{Sampling}

Enyalius bilineatus was collected in Cerrado areas of Área de Proteção Ambiental da Serra de São José (APASSJ), which is located in the foothills of the APASSJ in the municipality of Tiradentes $(N=12)$, and in the Reserva Biológica Unilavras-Boqueirão (RBUB) in the municipality of Ingaí $(N=8)$. We collected $E$. perditus in Atlantic Forest areas in Parque Estadual do Ibitipoca (PEI) in the municipality of Lima Duarte $(N=19)$ around Sítio Malícia, and in the Área de Proteção Ambiental Mata do Krambeck (APAMK; $N=6$ ) and Parque Municipal da Lajinha (PML; $N=3$ ) in Juiz de Fora (Figure 1).

All samples were collected in accordance to permits from the Sistema de Autorização e Informação da Biodiversidade-SISBIO (System for Biodiversity Information and Authorization), Instituto Estadual de Florestas-IEF (State Forestry Institute) and Agência Ambiental de Juiz de Fora (Juiz de Fora Environmental Agency) (AGENDA-JF) (license numbers 17917-1 to collect in Tiradentes, 17917-1 and 24661-1 in Ingaí, 772-1 in Lima Duarte and 17074-1 in Juiz de Fora, permission number $118 / 09$ to collect in APASSJ, 125/09 to collect in PEI and 69995/08 to collect in Conservation Units from Juiz de Fora). The project also was approved by the ethics committee of the animal experimentation, Comitê de Ética na Experimentação Animal da Pró-Reitoria de Pesquisa / UFJF (Protocol number 010/2008-CEA). 
We took liver parts from euthanized animals or tail samples $(2 \mathrm{~cm})$ from live animals. Tissues were stored at room temperature in $98 \%$ ethanol and added to the tissue collection of the UFJF, Minas Gerais. Total DNA was extracted using a phenol: chloroform: isoamyl-alcohol protocol (Sambrook et al. 1989) at the Genetics and Biotechnology Laboratory of UFJF.

\section{Cyt b Sequencing}

Partial $c y t b$ mitochondrial sequences were amplified using primers LGL 765 and H15144 (Bickham et al. 1995). PCR reaction mixes of
$20 \mu \mathrm{L}$, which included $4 \mu \mathrm{L}$ of genomic DNA ( $40 \mathrm{ng}$ ), $0.5 \mathrm{U}$ of Taq polymerase (Phoneutria ${ }^{\circledR}$ ), $200 \mu \mathrm{M}$ of dNTPs, $1 \mathrm{X}$ Tris-KCl buffer with 1.5 $\mathrm{mM} \mathrm{MgCl}{ }_{2}$ (Phoneutria $^{\circledR}$ ) and $0.5 \mu \mathrm{M}$ of each primer. The PCR profile consisted of $5 \mathrm{~min}$ at $94^{\circ} \mathrm{C}$, followed by 35 cycles of $30 \mathrm{~s}$ at $94^{\circ} \mathrm{C}$, $30 \mathrm{~s}$ at $52^{\circ} \mathrm{C}, 1 \mathrm{~min}$ at $72^{\circ} \mathrm{C}$ and a final extension step of $9 \mathrm{~min}$ at $72^{\circ} \mathrm{C}$. After amplification, the PCR products were checked by electrophoresis in $0.8 \%$ agarose gels and stained with Sybr Green. Negative controls in which template DNA was omitted, were used in all amplification runs. Only products with a single and welldefined 400-bp band were used in the sequencing

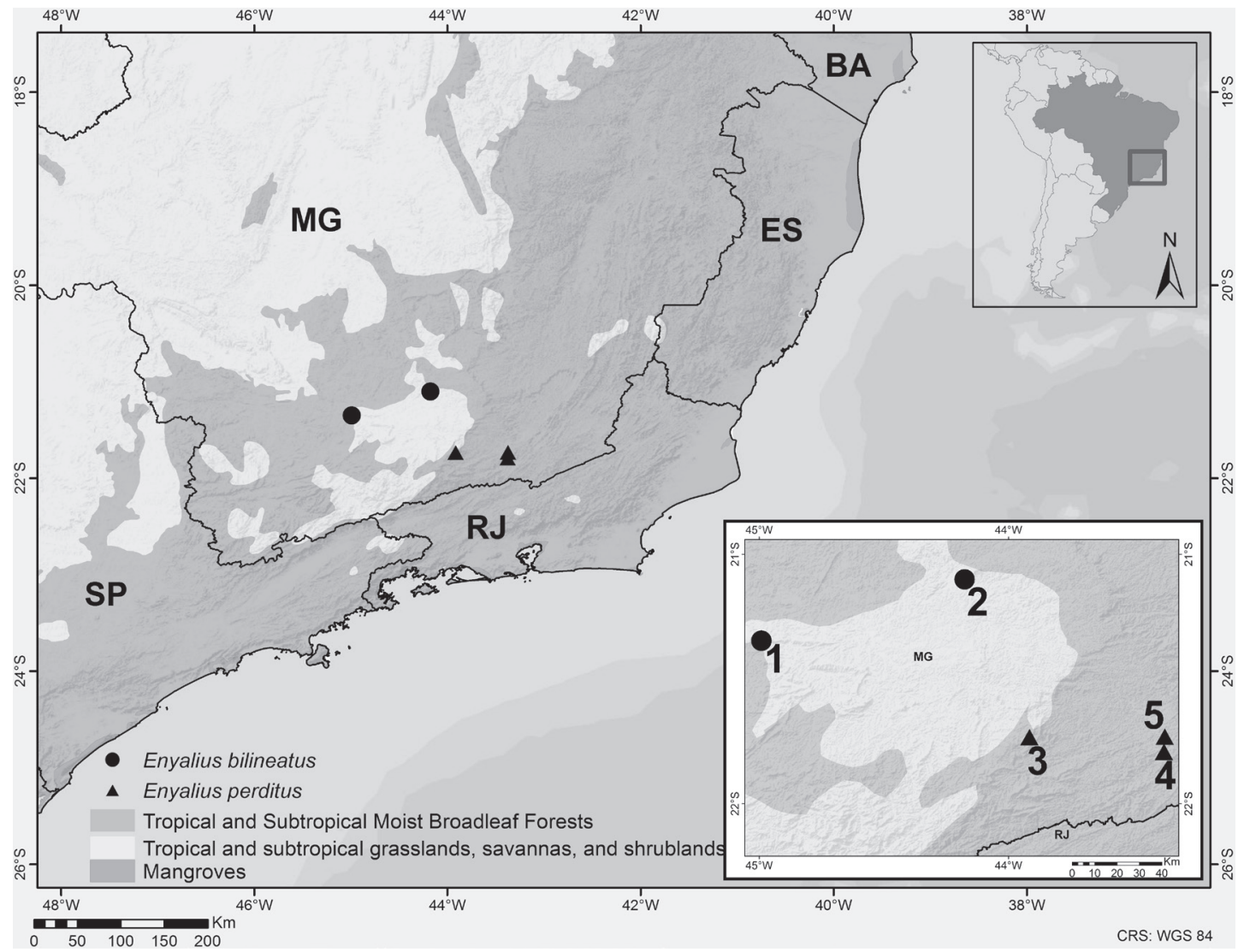

Figure 1. Map showing approximate location of sampling along Minas Gerais state, southeastern Brazil. Localities: 1. RBUB (Ingaí), 2. APASSJ (Tiradentes), 3. PEI (Lima Duarte), 4. PML (Juiz de Fora), 5. APAMK (Juiz de Fora). 
reactions. Before sequencing, PCR products were cleaned by precipitation using polyethyleneglicol (20\% PEG 8000, $2.5 \mathrm{M} \mathrm{NaCl})$. Forward and reverse sequencing reactions were performed at Embrapa Recursos Genéticos e Biotecnologia (Embrapa Genetic Resources and Biotechnology) using a final volume of $10 \mu \mathrm{L}$ that contained $2 \mu \mathrm{L}$ of purified PCR product, 3 $\mu \mathrm{L}$ of ultrapure water, $1 \mu \mathrm{L}$ of primer $(5 \mu \mathrm{M})$ and $4 \mu \mathrm{L}$ of sequencing kit (ET DYE Terminator Kit, GE Heathcare). Sequencing products were initially precipitated with ammonium acetate and ethanol, then dried at room temperature and dissolved with formamide-EDTA before being run in the automatic sequencer MegaBACE 1000 (GE Heathcare).

To generate high quality sequences, we undertook the following measures: (1) sequences longer than 400-bp were amplified; (2) chromatograms were checked carefully for ambiguities; (3) high quality consensus sequences were generated with forward and reverse sequences; and (4) consensus sequences produced for each individual in the present study were aligned and compared among them and with other sequences of species of Enyalius obtained from GenBank.

Sequence alignments were performed in MEGA v.6 (Tamura et al. 2013) and edited manually if necessary. Sequence divergences among different haplotypes within and among populations from this study and from Rodrigues et al. 2014 (GenBank 234-bp cyt b matched sequences from E. perditus-KM517705.1 to KM517713 and E. bilineatus-KM517659.1 to KM517663) were estimated in the same program using an uncorrected $P$ distances and Kimura 2-parameter (K2p) substitution model. Haplotypes numbers $(\mathrm{H})$, haplotype $(\mathrm{h})$ and nucleotide diversities $(\pi)$, the number of polymorphic sites (S), $F_{S T}$ and $\Phi_{\mathrm{ST}}$ using K2p distance method were calculated with Arlequin version 3.1 (Excoffier and Lischer 2010) only for the populations with $N \geq 3$ (our study). Median Joining (MJ) networks were constructed in the Network 4.6.1.3 (Bandelt et al. 1999), to depict the relationships among the 11 haplotypes of $E$. perditus and the eight of E. bilineatus (this study and Rodrigues et al. 2014).

\section{Results}

Despite amplifying a fragment of $400 \mathrm{bp}$, only sequences $234 \mathrm{bp}$ long were suitable for consensus sequencing. The 234-bp cyt $b$ fragment was analyzed for 20 samples of Enyalius bilineatus and 28 of Enyalius perditus. Eight novel haplotypes were found, five for $E$. perditus (two for PEI, two for APAMK and one for PML) and three for E. bilineatus (two for APASSJ and one for RBUB). We identified seven polymorphic sites in the haplotypes of E. perditus; 19 polymorphic sites were discovered in $E$. bilineatus (Table 1 and Figure 2). Figure 2 illustrates the relationship network among the haplotypes and frequencies identified for both species. A minimum of 37 steps was also found between the two groups of haplotypes (data not shown). Figure 2A shows the relationship among the five haplotypes found for individuals from PEI, PML and APAMK that, although not sharing haplotypes, have similar sequences (Table 1 and Figure 2A). Figure 2B shows the divergent haplotypes found in APASSJ and RBUB for E. bilineatus. Standard molecular diversity indices for analyzed samples are $h=$ 0.684 and $\pi=0.01015$ for E. perditus and $\mathrm{h}=$ 0.647 and $\pi=0.04163$ for E. bilineatus. The standard diversity indices for each population studied are summarized in Table 2. The $\Phi_{\text {ST }}$ values for among populations of $E$. perditus range from $0.368-0.700$, and 0.988 between the two populations of E. bilineatus (Table 3 ).

When the 14 sequences from 13 locations were included in the analysis (Rodrigues et al. 2014), we identified 11 and 8 haplotypes for $E$. perditus and E. bilineatus, respectively (Figure 3 ). Nucleotide divergences among populations for both species, which also included GenBank sequences (matched the 234-bp), are summarized in Tables 4 and 5. Nucleotide divergence between species is $20.30 \%$ ( $17.37 \%$ for uncorrected $P$ distance) and the mean distances within 
Table 1. Cyt $b$ polymorphisms and haplotype designations for Enyalius perditus ( $\mathrm{H} 1$ to $\mathrm{H} 5$ ) and E. bilineatus ( $\mathrm{H} 6$ to H8) assayed using 234-bp. The numbers at the top indicate the locations of polymorphic sites within the 234-base sequence.

\begin{tabular}{|c|c|c|c|c|c|c|c|c|c|c|c|c|c|c|c|c|c|c|c|}
\hline \multirow[b]{2}{*}{ E. perditus haplotypes } & \multicolumn{19}{|c|}{ Base position } \\
\hline & 1 & 2 & 3 & 1 & 1 & 1 & 2 & & & & & & & & & & & & \\
\hline & 2 & 6 & 5 & 7 & 7 & 9 & 1 & & & & & & & & & & & & \\
\hline & & & & 1 & 6 & 1 & 2 & & & & & & & & & & & & \\
\hline $\mathrm{H} 1$ & G & A & C & G & A & $\mathrm{C}$ & G & & & & & & & & & & & & \\
\hline $\mathrm{H} 2$ & $A$ & A & C & A & G & $\mathrm{T}$ & G & & & & & & & & & & & & \\
\hline $\mathrm{H} 3$ & $A$ & A & A & A & G & $\mathrm{T}$ & G & & & & & & & & & & & & \\
\hline $\mathrm{H} 4$ & G & G & C & A & A & $\mathrm{T}$ & A & & & & & & & & & & & & \\
\hline $\mathrm{H} 5$ & G & G & C & A & A & $\mathrm{T}$ & A & & & & & & & & & & & & \\
\hline \multirow[t]{3}{*}{ E. bilineatus haplotypes } & 8 & 2 & 8 & 8 & 9 & 1 & 1 & 1 & 1 & 1 & 1 & 1 & 1 & 1 & 1 & 1 & 1 & 2 & 2 \\
\hline & & 6 & 3 & 6 & 6 & 0 & 1 & 2 & 3 & 3 & 4 & 5 & 5 & 7 & 8 & 8 & 9 & 0 & 0 \\
\hline & & & & & & 4 & 3 & 2 & 4 & 7 & 3 & 2 & 8 & 3 & 5 & 8 & 7 & 5 & 6 \\
\hline $\mathrm{H} 6$ & $\mathrm{~T}$ & $\mathrm{~T}$ & $\mathrm{C}$ & $\mathrm{T}$ & G & C & $\mathrm{T}$ & C & C & A & A & $C$ & $\mathrm{~T}$ & C & $\mathrm{T}$ & $\mathrm{T}$ & $\mathrm{T}$ & G & A \\
\hline $\mathrm{H} 7$ & $\mathrm{~T}$ & $\mathrm{~T}$ & $\mathrm{C}$ & $\mathrm{T}$ & G & C & $\mathrm{T}$ & $\mathrm{C}$ & C & A & A & $\mathrm{C}$ & $\mathrm{T}$ & $\mathrm{C}$ & $\mathrm{T}$ & $\mathrm{T}$ & $\mathrm{T}$ & G & $\mathrm{C}$ \\
\hline $\mathrm{H} 8$ & C & $\mathrm{C}$ & $\mathrm{T}$ & C & A & $\mathrm{T}$ & C & $\mathrm{T}$ & $\mathrm{T}$ & $\mathrm{G}$ & C & $\mathrm{T}$ & C & $\mathrm{T}$ & $\mathrm{C}$ & $\mathrm{C}$ & C & A & $\mathrm{T}$ \\
\hline
\end{tabular}

Table 2. Number of samples $(N)$, number polymorphic sites $(S)$, absolute haplotype frequencies $(H)$, haplotype $(h)$ and nucleotide $(\pi)$ diversities for Enyalius perditus and $E$. bilineaus populations using 234-bp of the mtDNA gene cyt $b$.

\begin{tabular}{|c|c|c|c|c|c|c|}
\hline Location & Size of sampled areas (ha) & $N$ & $\mathbf{S}$ & $\mathbf{H}$ & $\mathbf{h}$ & $\pi$ \\
\hline PEI (Lima Duarte) & 1,488 & 19 & 4 & 2 & $0.351 \pm 0.111$ & 0.00600 \\
\hline APAMK (Juiz de Fora) & 292.89 & 6 & 4 & 2 & $0.600 \pm 0.129$ & 0.01026 \\
\hline PML (Juiz de Fora) & 88 & 3 & 0 & 1 & 0 & 0 \\
\hline Overall E. perditus & & 28 & 7 & 5 & $0.683 \pm 0.081$ & 0.01015 \\
\hline APASSJ (Tiradentes) & 4,758 & 12 & 1 & 2 & $0.409 \pm 0.133$ & 0.00175 \\
\hline RBUB (Ingaí) & 159.5 & 8 & 0 & 1 & 0 & 0 \\
\hline Overall E. bilineatus & & 20 & 19 & 3 & $0.647 \pm 0.057$ & 0.04163 \\
\hline
\end{tabular}


Table 3. Population pairwise $\mathrm{F}_{\mathrm{ST}}$ based on haplotype frequencies (below diagonal) and $\Phi_{\mathrm{ST}}$ using $\mathrm{K} 2 \mathrm{p}$ distance method (above diagonal) between Enyalius perditus and E. bilineatus populations (all values were significant with $P$ $<0.05)$.

\begin{tabular}{|c|c|c|c|c|c|}
\hline Location & $\begin{array}{c}\text { PEI } \\
\text { E. perditus } \\
\end{array}$ & $\begin{array}{c}\text { APAMK } \\
\text { E. perditus }\end{array}$ & $\begin{array}{c}\text { PML } \\
\text { E. perditus } \\
\end{array}$ & $\begin{array}{c}\text { APASSJ } \\
\text { E. bilineatus }\end{array}$ & $\begin{array}{c}\text { RBUB } \\
\text { E. bilineatus } \\
\end{array}$ \\
\hline PEI (Lima Duarte) & - & 0.368 & 0.700 & 0.979 & 0.978 \\
\hline APAMK (Juiz de Fora) & 0.571 & - & 0.601 & 0.978 & 0.977 \\
\hline PML (Juiz de Fora) & 0.710 & 0.600 & - & 0.993 & 1.000 \\
\hline APASSJ (Tiradentes) & 0.628 & 0.518 & 0.681 & - & 0.988 \\
\hline RBUB (Ingaí) & 0.763 & 0.741 & 1.000 & 0.759 & - \\
\hline
\end{tabular}

species are $2.03 \%(1.97 \%$ for uncorrected $P$ distance) for E. perditus and 5.63\% (5.20\% for uncorrected $P$ distance) for $E$. bilineatus (data not shown).

Figure 3 illustrates the two networks of our data, as well as those of Rodrigues et al. (2014), for both species. The first network (Figure 3A) depicts 11 E. perditus haplotypes (corresponding 24 polymorphic sites) that are grouped in two divergent clades. The second network shows $E$. bilineatus haplotypes (corresponding 41 polymorphic sites) grouped in, at least, four divergent clades (Figure 3B).

\section{Discussion}

The genetic diversity values of the two species of Enyalius examined are similar; however, the patterns of genetic structure are distinct. Most species of Enyalius have highly restricted habitat preferences (Atlantic Forest), but $E$. bilineatus is more broadly distributed. This species also occurs in open gallery forests of Cerrado and close to coffee plantations (Teixeira et al. 2005). Enyalius bilineatus also is an older lineage (mean time to the most recent common ancestor around of 6.86 mya) than $E$. perditus (mean time to the most recent common ancestor around of 4.2 mya) (Rodrigues et al.
2014); thus, E. bilineatus has had a longer time to accumulate genetic variation.

\section{Enyalius perditus}

Despite the low sample size $(N=6)$, the population of E. perditus from APAMK (the larger intact Atlantic Forest fragment studied here; 292 ha) has the highest haplotype and nucleotide diversity values (Table 2). The mean sequence distance found among populations of E. perditus are highly similar (Table 4). We identified an exclusive haplotype from the PML (Juiz de Fora) population; thus, this population likely is isolated from the other populations.

Although more distant (55 Km apart), the mean sequence divergence and the $\Phi_{\text {ST }}$ between PEI and APAMK (1.2\% and 0.37 , respectively) are lower than in the two populations of Juiz de Fora (APAMK and PML-1.7\% and 0.60) that are only $6.5 \mathrm{Km}$ apart. This absence of shared haplotypes among populations of E. perditus may reflect a sampling artifact, given that the sample sizes for PML and APAMK are low $(N=$ 3 and $N=6$, respectively). Thus, it is possible that our sampling may not represent overall population diversity. Based on a comparison of overall diversity for E. perditus (Figure 3), two divergent clades are apparent. Our samples are 
A

PEI (Lima Duarte)

$\square$ APAMK (Juiz de Fora)

$\square$ PML (Juiz de Fora)

H3

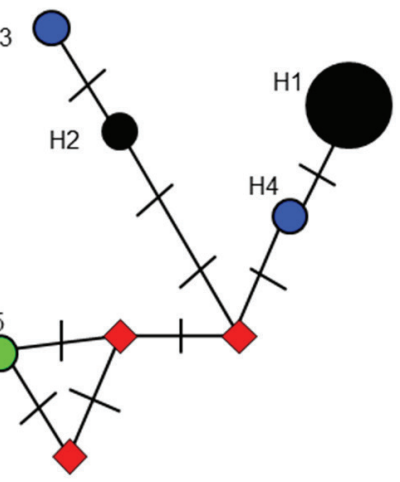

B

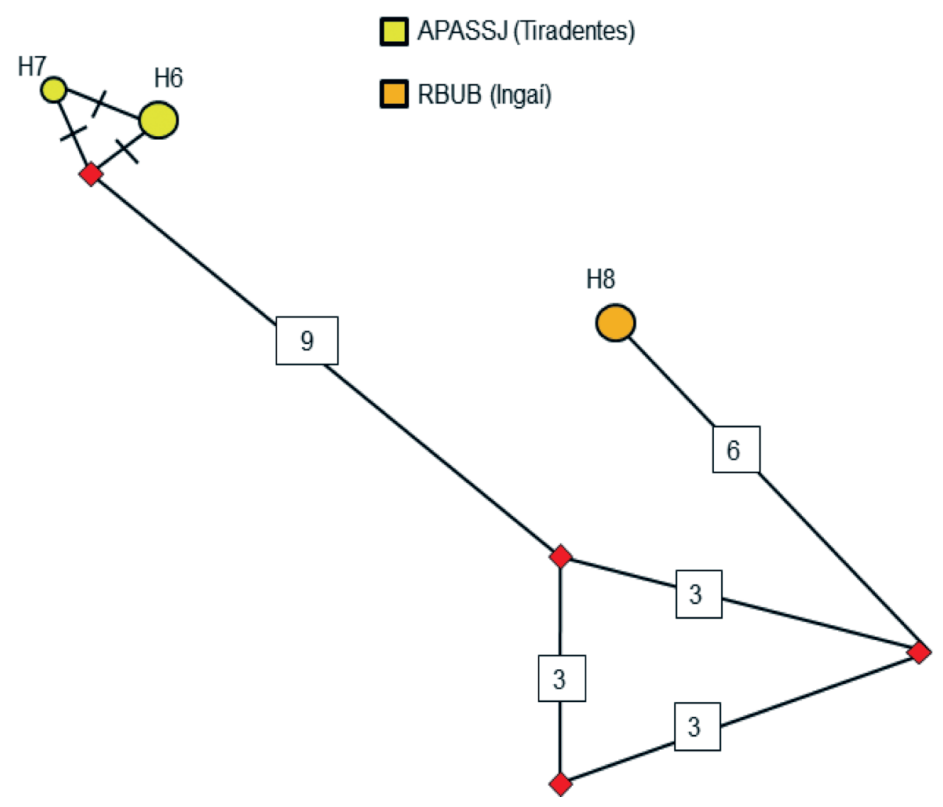

Figure 2. MJ networks describing the relationship among the Enyalius mtDNA haplotypes (234-bp). The relationship among the five haplotypes of E. perditus is shown on the left (A), that of the haplotypes of E. bilineatus is on the right $(\mathbf{B})$. $\mathrm{H} 1$ to $\mathrm{H} 8$ represents the Haplotypes $1-8$. The median vectors are represented by the red diamonds. The values inside the squares are mutational points. The sizes of the circles size represent the frequencies of each haplotype.

more similar to those sequences reported by Rodrigues et al. (2014) for clade "Eper2." Thus, the inclusion of samples of E. perditus from other localities from Minas Gerais did not clarify the putative paraphyly of the species (Rodrigues et al. 2014). The "Eper1" clade is associated with the coastal areas of the state of Sao Paulo; thus, additional samples should be collected from these areas, and from transitional areas between coastal and inland areas in the state of Rio de Janeiro.

\section{Enyalius bilineatus}

Enyalius bilineatus from APASSJ has the highest diversity values (Table 2). The samples from both RBUB and APASSJ were identified as
E. bilineatus; however, the populations did not share any haplotypes, and they differed by 19 mutational steps (Figure 2).

The mean uncorrected sequence distance of $8.8 \%$ between the two populations of Enyalius bilineatus is greater than expected for divergence values within a single species. The lack of shared haplotypes, the many mutational steps, the high level of $\mathrm{F}_{\mathrm{ST}}(0.759)$ and $\Phi_{\mathrm{ST}}(0.988)$, and the high genetic distance between these two populations of E. bilineatus suggests that there is great genetic divergence within the same species. Furthermore, comparison of our sequences with those of Rodrigues et al. (2014) yields a sequence divergence value of $14.5 \%$ between samples from Brasilia (DF) and Mariana (MG). The two haplotypes found at APASSJ are also divergent 
A

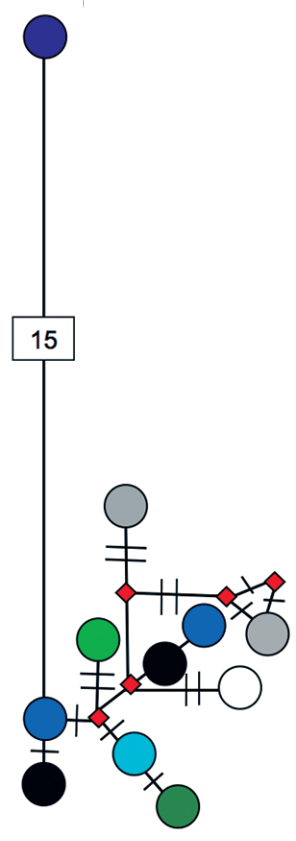

B

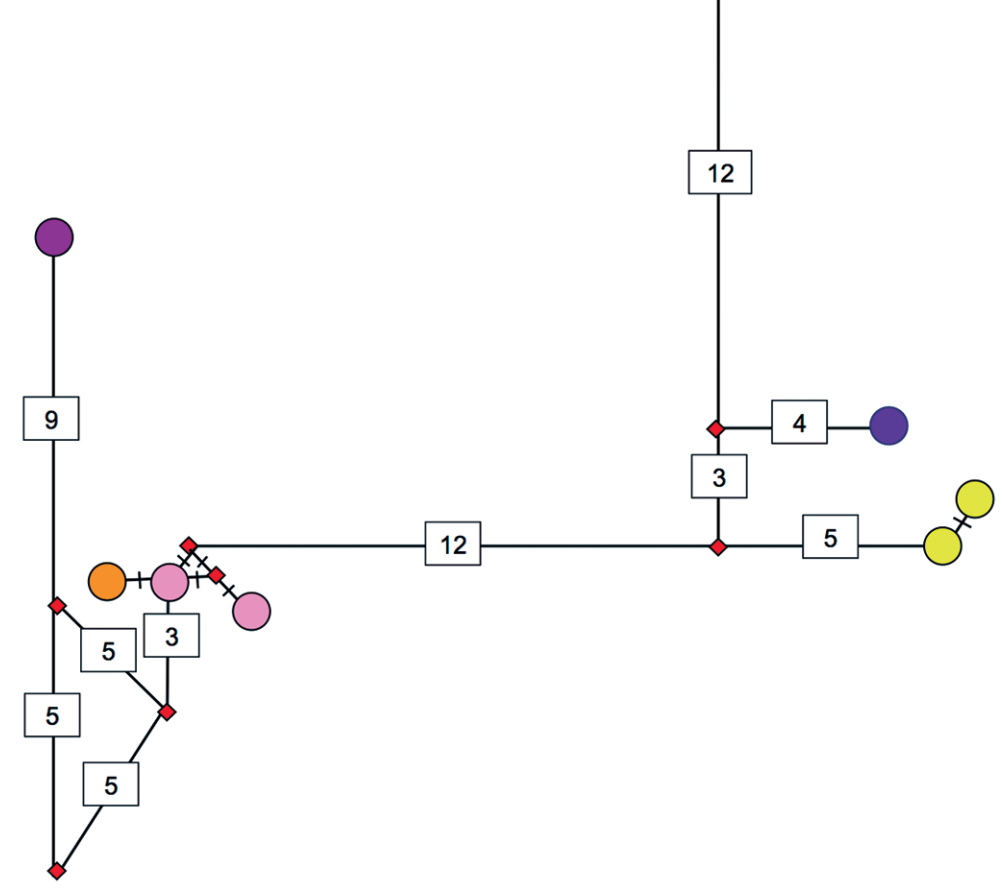

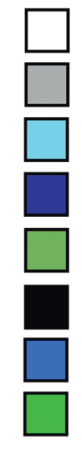

PN Caparaó ES/MG (KM517706.1 and KM517705.1)

Rocio and Nova Friburgo RJ (KM517711.1 and KM517709.1)

Lambari MG (KM517707.1)

Salesópolis/Juquitiba SP-Ep2 (KM517712.1 and KM517713.1)

Pirajú SP and Ortigueira PR (KM517708.1 and KM517710.1)

PEI - Lima Duarte MG

APAMK - Juiz de Fora MG

PML - Juiz de Fora MG

Figure 3. MJ networks describing the relationship among the Enyalius mtDNA haplotypes (234-bp). The relationship among the 11 haplotypes of E. perditus is shown on the left (A), and that of the eight haplotypes of $E$. bilineatus is on the right (B; this study and Rodrigues et al. [2014]). The median vectors are represented by the red diamonds. The values inside the squares are the mutational points. The sizes of the circles size do not reflect the frequencies of samples from each haplotype. 
Table 4. Mean sequence divergence between 12 pairs of populations of Enyalius perditus and within populations (diagonal - underlined numbers), from this study and Rodrigues et al. (2014). Above diagonal - uncorrected $P$-distance and below diagonal - corrected K2p.

\begin{tabular}{|c|c|c|c|c|c|c|c|c|c|c|c|c|}
\hline E. perditus populations & 1 & 2 & 3 & 4 & 5 & 6 & 7 & 8 & 9 & 10 & 11 & 12 \\
\hline 1 - PEI - Lima Duarte MG & $\underline{0.006}$ & 0.012 & 0.017 & 0.020 & 0.020 & 0.013 & 0.010 & 0.028 & 0.010 & 0.032 & 0.070 & 0.070 \\
\hline 2 - APAMK - Juiz de Fora MG & 0.012 & $\underline{0.010}$ & 0.017 & 0.017 & 0.017 & 0.013 & 0.017 & 0.026 & 0.017 & 0.028 & 0.073 & 0.073 \\
\hline 3 - PML - Juiz de Fora MG & 0.017 & 0.017 & $\underline{0.000}$ & 0.021 & 0.021 & 0.013 & 0.017 & 0.030 & 0.017 & 0.034 & 0.068 & 0.068 \\
\hline 4 - Caparaó ES & 0.020 & 0.017 & 0.022 & $\underline{0.000}$ & 0.000 & 0.017 & 0.021 & 0.026 & 0.021 & 0.030 & 0.073 & 0.073 \\
\hline 5 - Caparaó MG & 0.020 & 0.017 & 0.022 & 0.000 & $\underline{0.000}$ & 0.017 & 0.021 & 0.026 & 0.021 & 0.030 & 0.073 & 0.073 \\
\hline 6 - Lambari MG & 0.013 & 0.013 & 0.013 & 0.017 & 0.017 & $\underline{0.000}$ & 0.004 & 0.026 & 0.004 & 0.030 & 0.073 & 0.073 \\
\hline 7 - Ortigueira SP & 0.010 & 0.017 & 0.017 & 0.022 & 0.022 & 0.004 & $\underline{0.000}$ & 0.030 & 0.000 & 0.034 & 0.077 & 0.077 \\
\hline 8 - Rocio RJ & 0.029 & 0.026 & 0.031 & 0.026 & 0.026 & 0.026 & 0.031 & $\underline{0.000}$ & 0.030 & 0.021 & 0.085 & 0.085 \\
\hline 9 - Pirajú SP & 0.010 & 0.017 & 0.017 & 0.022 & 0.022 & 0.004 & 0.000 & 0.031 & $\underline{0.000}$ & 0.034 & 0.077 & 0.077 \\
\hline 10 - Nova Friburgo RJ & 0.033 & 0.028 & 0.035 & 0.031 & 0.031 & 0.031 & 0.035 & 0.022 & 0.035 & $\underline{0.000}$ & 0.081 & 0.081 \\
\hline 11 - Juquitiba SP & 0.074 & 0.077 & 0.072 & 0.077 & 0.077 & 0.077 & 0.082 & 0.092 & 0.082 & 0.087 & $\underline{0.000}$ & 0.000 \\
\hline 12 - Salesópolis SP & 0.074 & 0.077 & 0.072 & 0.077 & 0.077 & 0.077 & 0.082 & 0.092 & 0.082 & 0.087 & 0.000 & $\underline{0.000}$ \\
\hline
\end{tabular}

(5.5\% and 12 mutational steps) from the haplotype found for Mariana (MG), despite the populations being separated by only $120 \mathrm{Km}$ (Table 5).

The least genetic divergence found in populations of Enyalius bilineatus (0.9\%) is between RBUB and Nova Ponte (MG) sequences (Table 5). Although these populations are separated by more than $380 \mathrm{Km}$, the individuals sampled occupy similar open areas of Cerrado. These individuals differ from the other clade, which comprises samples from eastern areas of high altitude near or along the Atlantic Forest (Figure 3B).

It is apparent that Enyalius bilineatus probably is composed of two major lineages that are associated with different habitats rather than geographic distance-one is associated with the open areas of Cerrado, whereas the other occupies high-altitude environments in and around Atlantic Forest fragments. In addition, we also noted greater divergence among haplotypes within each clade than for E. perditus (Figure 3B).

The genetic divergence values identified among populations of Enyalius bilineatus (Table 5) are higher than those among individual lizards reported in studies that used the same $c y t b$ marker. For example, Thorpe et al. (2005) reported 5.2-5.7\% sequence divergence within Anolis extremus in Barbados. Others studies have documented values of uncorrected genetic distances from $4.2-6.5 \%$ for three Fijian iguana (Brachylophus) species (Keogh et al. 2008) and from $0.0-3.57 \%$ for species of Uma in North America (Trépanier and Murphy 2001). However, one study of scrub lizards (Sceloporus 
Table 5. Mean sequence divergence between six pairs of populations of Enyalius bilineatus and within populations (diagonal - underlined numbers), from this study and Rodrigues et al. (2014). Above diagonal - uncorrected $P$-distance and below diagonal - corrected K2p.

\begin{tabular}{lcccccc}
\hline E. bilineatus populations & $\mathbf{1}$ & $\mathbf{2}$ & $\mathbf{3}$ & $\mathbf{4}$ & $\mathbf{5}$ & $\mathbf{6}$ \\
\hline 1 - APASS - Tiradentes MG & $\underline{0.002}$ & 0.088 & 0.111 & 0.084 & 0.079 & 0.052 \\
2 - RBUB - Ingaí MG & 0.081 & $\underline{0.000}$ & 0.077 & 0.073 & 0.009 & 0.090 \\
3 - Brasilia DF & 0.124 & 0.083 & $\underline{0.009}$ & 0.103 & 0.077 & 0.128 \\
4 - Santa Teresa ES & 0.092 & 0.079 & 0.114 & $\underline{0.000}$ & 0.071 & 0.068 \\
5 - Nova Ponte MG & 0.085 & 0.009 & 0.083 & 0.076 & $\underline{0.000}$ & 0.088 \\
6 - Mariana MG & 0.055 & 0.098 & 0.145 & 0.073 & 0.095 & $\underline{0.000}$ \\
\hline
\end{tabular}

woodi) in Florida reported a genetic distances of 1-10\% (Clark et al. 1999); the authors questioned the taxonomic status of this species, given the evolutionary partitions evident in the data.

This study is the first to document the genetic diversity and structure of two species of Enyalius. The results suggest that populations of Enyalius bilineatus are genetically divergent and contain cryptic diversity, thereby confirming the conclusions of Rodrigues et al. (2014). The divergence reflects the habitat preferences of the species (open areas of Cerrado vs. Atlantic Forest fragments). We also found abundant variation among haplotypes within clades, suggesting the existence of more hidden diversity than previously documented.

Complementary studies on the ecology, behavior, and morphology-as proposed by Pellegrino et al. (2005) for species limits in the Gymnodactylus darwinii complex, should be undertaken to determine whether (1) the differences reported herein are associated with other biological aspects of this species, or if (2) they are unique to the molecular marker used in this study. When viewed in an ecological context, our results will contribute to a better understanding of the taxonomic and conservation status of Enyalius.

\section{Acknowledgments}

We thank Talita Mota Machado for preparing Figure 1, and Ramon Gomes de Carvalho, Israel Tadeu Trindade, Diego Arnaldo Neto-Silva, and Fernando Antonio Frieiro-Costa for their help with fieldwork. We are grateful to Nathan Emery and Rita Rocha for helpful comments on the manuscript. This work was supported by the Fundação de Amparo à Pesquisa do Estado de Minas Gerais (FAPEMIG) (Grants numbers: CRA APQ 01992-09 and 01792-10). SMV was supported by Coordenação de Aperfeiçoamento de Pessoal de Nível Superior CAPES/PNPD, BMS by Conselho Nacional de Desenvolvimento Científico e Tecnológico (CNPq), RMP, LMCL, PC and SM by Pró-Reitoria de Pesquisa da Universidade Federal de Juiz de Fora (PROBIC/ UFJF).

\section{References}

Ávila-Pires, T. C. S. 1995. Lizards of Brazilian Amazonia (Reptilia: Squamata). Zoologische Verhandelingen 299: $1-706$.

Bandelt, H. J., P. Forster, and A. Röhl. 1999. Median-joining networks for inferring intraspecific phylogenies. Molecular Biology Evolution 16: 37-48. 
Barreto-Lima, A. F. B. 2012. Distribuição, nicho potencial e ecologia morfológica do gênero Enyalius (Squamata, Leiosauridae): testes de hipóteses para lagartos de florestas continentais brasileiras. Unpublished $\mathrm{PhD}$. Dissertation. Universidade Federal do Rio Grande do Sul, Porto Alegre, Brazil.

Bertolotto, C. E. V. 2006. Enyalius (Leiosauridae, Squamata): o que os dados moleculares e cromossômicos revelam sobre esse gênero de lagartos endêmico do Brasil. Unpublished $\mathrm{PhD}$. Dissertation. Universidade de São Paulo, Brazil.

Bertolotto, C. E. V., K. C. Pellegrino, M. T. Rodrigues, and Y. Yonenaga-Yassuda. 2002. Comparative cytogenetics and supernumerary chromosomes in the Brazilian lizards genus Enyalius (Squamata, Polichrotidae). Hereditas 136: $51-57$.

Bickham J. W., C. C. Wood, and J. C. Patton. 1995. Biogeographic implications of cytochrome $b$ sequences and allozymes in sockeye (Oncorhynchus nerka). Journal of Heredity 86:140-144.

Clark, A. M., B. W. Bowen, and L. C. Branch. 1999. Effects of natural habitat fragmentation on an endemic scrub lizard (Sceloporus woodi): an historical perspective based on a mitochondrial DNA gene genealogy. Molecular Ecology 8: 1093-1104.

Colli, G. R. 2003. Estrutura de taxocenoses de lagartos em fragmentos naturais e antrópicos de Cerrado. Pp. 171178 in V. Claudino-Sales (ed), Ecossistemas Brasileiros: Manejo e Conservação. Fortaleza. Expressão Gráfica e Editora.

Etheridge, R. 1969. A review of the iguanid lizard genus Enyalius. Bulletin of the British Museum, Zoology 18 : 231-260.

Excoffier, L. and H. E. L. Lischer. 2010. Arlequin suite ver 3.5: a new series of programs to perform population genetics analyses under Linux and Windows. Molecular Ecology Resources 10: 564-567.

Frankham, R., J. D. Ballou, and D. A. Briscoe (eds). 2010. Conservation Genetics. $2^{\text {nd }}$ Edition. Cambridge. Cambridge University Press. 644 pp.

IUCN (ed.). 2015. Red List IUCN. Version 2014.3 (10 April 2015) Eletronic Database acessible at http//www. iucnredlist.org. USA. Captured on 22 April 2015.

Jackson, J. F. 1978. Differentiation in the genera Enyalius and Strobilurus (Iguanidae): implications for Pleistocene climatic changes in eastern Brazil. Arquivos de Zoologia 30: $1-79$.

Keogh, J. S., D. L. Edwards, R. N. Fisher, and P. S. Harlow. 2008. Molecular and morphological analysis of the critically endangered Fijian iguanas reveals cryptic diversity and complex biogeographic history. Philosophical Transactions of the Royal Society 363: 34133426.

Martins, M. and F. B. Molina. 2008. Panorama geral dos répteis ameaçados do Brasil. Pp. 327-334 in A. B. M. Machado, G. M. Drummond, and A. P. Paglia (eds.), Livro Vermelho da Fauna Brasileira Ameaçada de Extinção. Brasília and Belo Horizonte. Fundação Biodiversitas.

Novelli, I. A., P. S. Lucas, R. G. Carvalho, R. C. Santos, and B. M. Sousa. 2012. Lagartos em áreas de Cerrado na Reserva Biológica Unilavras-Boqueirão, Ingaí, sul de Minas Gerais, Brasil. Biota Neotropica 12: 147-153.

O'Brien, S. J. 1994. A role for molecular genetics in biological conservation. Proceedings of the National Academy of Science of the United States of America 91: $5748-5755$.

Pellegrino, K. C. M., M. T. Rodrigues, A. N. Waite, M. Morando, Y. Y. Yassuda, and J. W. Sites Jr. 2005. Phylogeography and species limits in the Gymnodactylus darwinii complex (Gekkonidae, Squamata): genetic structure coincides with river systems in the Brazilian Atlantic Forest. Biological Journal of the Linnean Society 85: 13-26.

Rodrigues, M. T., C. E. V. Bertolotto, R. C. Amaro, Y. Yonenaga-Yassuda, E. M. Freire, and K. C. M. Pellegrino. 2014. Molecular phylogeny, species limits, and biogeography of the Brazilian endemic lizard genus Enyalius (Squamata: Leiosauridae): an example of the historical relationship between Atlantic Forests and Amazonia. Molecular Phylogenetics and Evolution 81: 137-146.

Sambrook J., E. F. Fritsch, and T. Maniatis (eds.). 1989. Molecular Cloning: a Laboratory Manual. $2^{\text {nd }}$ Edition. New York. Cold Spring Harbor Laboratory Press. 1659 pp.

Santos, F. R. and R. A. F. Redondo. 2003. A biotecnologia aplicada à conservação de espécies silvestres. Pp. 127151 in A. Borém, M. R. Almeida, and F. R. Santos (eds.), Biotecnologia de A a Z. Viçosa. Universidade Federal de Viçosa.

Sousa, B. M., A. E. R. Nascimento, S. C. Gomides, C. H. V. Rios, A. A. Hudson, and I. A. Novelli. 2010. Répteis em fragmentos de Cerrado e Mata Atlântica no Campo das Vertentes, estado de Minas Gerais, sudeste do Brasil. Biota Neotropica 10:129-138.

Sousa, B. M., S. C. Gomides, A. A. Hudson, L. B. Ribeiro, and I. A. Novelli. 2012. Reptiles of the municipality of Juiz de Fora, Minas Gerais state, Brazil. Biota Neotropica 12: 35-49. 
Tamura, K., G. Stecher, D. Peterson, A. Filipski, and S. Kumar. 2013. MEGA6: Molecular Evolutionary Genetics Analysis version 6.0. Molecular Biology and Evolution 30: 2725-2729.

Teixeira, R. L., K. Roldi, and D. Vrcibradic. 2005. Ecological comparisons between the sympatric lizards Enyalius bilineatus and Enyalius brasiliensis (Iguanidae, Leiosaurinae) from an Atlantic Rain-Forest in Southeastern Brazil. Journal of Herpetology 39: 504-509.

Thorpe, R. S., D. L. Leadbeater, and C. E. Pook. 2005. Molecular clocks and geological dates: cytochrome $b$ of Anolis extremus substantially contradicts dating of Barbados emergence. Molecular Ecology 14: 2087-2096.

Trépanier, T. L. and R. W. Murphy. 2001. The Coachella Valley fringe-toed lizard (Uma inornata): genetic diversity and phylogenetic relationships of an endangered species. Molecular Phylogenetics and Evolution 18: 327-334.
Vanzolini, P. E., 1973. Garbesauria garbei Amaral, 1933, a synonym of Enyalius leechii (Boulenger, 1885) (Sauria: Iguanidae). Papéis Avulsos de Zoologia 27: 173-175.

Wallace, B. P., A. D. DiMatteo, A. B. Bolten, M. Y. Chaloupka, B. J. Hutchinson, F. A. Abreu-Grobois, J. A. Mortimer, J. A. Seminoff, D. Amorocho, K. A. Bjorndal, J. Bourjea, B. W. Bowen, R. Briseño Dueñas, P. Casale, B. C. Choudhury, A. Costa, P. H. Dutton, A. Fallabrino, E. M. Finkbeiner, A. Girard, M. Girondot, M. Hamann, B. J. Hurley, M. López-Mendilaharsu, M. A. Marcovaldi, J. A. Musick, R. Nel, N. J. Pilcher, S. Troëng, B. Witherington, and R. B. Mast. 2011. Global conservation priorities for marine turtles. PLoS One 6: e24510.

Zamprogno, C., M. G. F. Zamprogno, and R. L. Teixeira. 2001. Evidence of terrestrial feeding in the arboreal lizard Enyalius bilineatus (Sauria, Polychrotidae) of southeastern Brazil. Revista Brasileira de Biologia 61: 91-94.

Editor: James Bogart 